\title{
Extraction and Simultaneous Determination of Glyphosate, AMPa ANd Compounds of The Shikimic Acid Pathway IN Plants $^{1}$
}

\author{
Extração e Determinação Simultânea de Glyphosate, AMPA e Compostos da Rota do Ácido \\ Chiquímico em Plantas
}

GOMES, G.L.G.C. ${ }^{2}$, CARBONARI, C.A. ${ }^{2}$, VELINI, E.D. ${ }^{2}$, TRINDADE, M.L.B. ${ }^{3}$, and SILVA, J.R.M. ${ }^{2}$

\begin{abstract}
This study has aimed to develop a method for simultaneous extraction and determination by liquid chromatography and mass spectrometry (LC-MS/MS) of glyphosate, aminomethylphosphonic acid (AMPA), shikimic acid, quinic acid, phenylalanine, tyrosine and tryptophan. For the joint analysis of these compounds the best conditions of ionization in mass spectrometry and for chromatographic separation of the compounds were selected. Calibration curves and linearity ranges were also determined for each compound. Different extraction systems of the compounds were tested from plant tissues collected from sugarcane (Saccharum officinarum) and eucalyptus (Eucalyptus urophylla platiphylla) plants two days after the glyphosate application at the dose of $720 \mathrm{~g}$ a.e. ha $\mathrm{a}^{-1}$. The plant material was dried in a forced air circulation drying oven and in a lyophilizer, and subsequently the extractions with acidified water ( $\mathrm{pH} 2.5)$, acetonitrile-water (50:50) [v/v] and methanol-water (50:50) [v/v] were tested. To verify the recovery of the compounds in the plant matrix with acidified water as an extracting solution, the samples were fortified with a solution containing the mixture of the different analytical standards present so that this one presented the same levels of 50 and $100 \mu \mathrm{g} \mathrm{L}^{-1}$ of each compound. All experiments were conducted with three replicates. The analytical method developed was efficient for compounds quantifications. The extraction from the samples dried in an oven and using acidified water allowed better extraction levels for all compounds. The recovery levels of the compounds in the fortified samples with known amounts of each compound for both plants samples were rather satisfactory.
\end{abstract}

Keywords: herbicide, LC-MS/MS, metabolites, metabolic profile.

\begin{abstract}
RESUMO - Este trabalho teve como objetivo o desenvolvimento de um método de extração e determinação simultânea por cromatografia líquida e espectrometria de massas (LC-MS/MS) de glyphosate, ácido aminometilfosfônico (AMPA), ácido chiquímico, ácido quinico, fenilalanina, tirosina e triptofano. Para a análise conjunta desses compostos, foram selecionadas as melhores condições de ionização no espectrômetro de massas e para a separação cromatográfica dos compostos. Também foram determinadas as curvas de calibração e faixas de linearidade para cada um dos compostos. Foram testados diferentes sistemas de extração dos compostos a partir de tecidos vegetais coletados de planta de cana-de-açúcar (Saccharum officinarum) e eucalipto (Eucalyptus urophylla platiphylla) aos dois dias após receberem a aplicação de glyphosate na dose de $720 \mathrm{~g}$ e.a. ha $\mathrm{h}^{-1}$. O material vegetal foi seco em estufa de circulação forçada de ar e em um liofilizador, sendo posteriormente testadas as extrações com água acidificada ( $\mathrm{pH}$ 2,5), acetonitrila-água (50:50) [v/v] e metanol-água (50:50) [v/v]. Para verificação da recuperação dos compostos na matriz vegetal com água acidificada como solução extratora, foi realizada a fortificação das amostras com uma solução contendo a mistura dos diferentes padrões analiticos, para que esta apresentasse os teores de 50 e $100 \mu \mathrm{g} \mathrm{L}^{-1}$ de cada composto. Todos os experimentos foram realizados com três repetições. O método analítico desenvolvido
\end{abstract}

1 Recebido para publicação em 18.11.2014 e aprovado em 26.1.2015.

2 Universidade Estadual Paulista “Júlio de Mesquita Filho”, Faculdade de Ciências Agronômicas, Botucatu-SP, Brasil, <gomes.glgc@gmail.com>; ${ }^{3}$ Bioativa, Botucatu-SP, Brasil. 
foi eficiente para quantificação dos compostos. A extração a partir de amostras secas em estufa e com água acidificada permitiu a melhor extração para todos os compostos. Os niveis de recuperação dos compostos nas amostras fortificadas com quantidade conhecida de cada composto, para as duas matrizes, foram bastante satisfatórios.

Palavras-chave: herbicida, LC-MS/MS, metabólitos, perfil metabólico.

\section{INTRODUCTION}

Glyphosate is the only commercial herbicide which blocks the 5-enolpyruvylshikimate 3-phosphate synthase (EPSPS) and has a number of favorable characteristics that make it safe from a toxicological and environmental standpoint, besides presenting a broad spectrum of control and large effectiveness in weed control. Inhibition of the enzyme EPSPS by the action of glyphosate affects the shikimic acid pathway, which consists of seven metabolic steps (Maeda \& Dudareva, 2012). Chorismate, the end product of the pathway of shikimic acid and the first waypoint of the pathway, is the precursor of the three aromatic amino acids: phenylalanine, tyrosine and tryptophan.

The three aromatic amino acids are precursors to a wide variety of secondary metabolites of plants (Maeda \& Dudareva, 2012). The intermediates of the shikimate pathway also serve as a starting point for the biosynthesis of secondary products; thus, this pathway is of great importance for the synthesis of many compounds of commercial interest (Herrmann \& Weaver, 1999; Matallo et al., 2014). The intermediates of the pathway of the shikimic acid also give rise to many compounds involved in growth regulation or in plant defense, especially the condensed tannins, anthocyanins, vitamin E, indole-3acetic acid (IAA), salicylic acid, flavones, isoflavones, phenylpropanoids and coumarins, which are essential for plant growth and development.

The extraction and quantification of various compounds related to the shikimate pathway are extremely important in the detection of plants injury to herbicide glyphosate, as well as in the identification of resistant weeds to this herbicide. The shikimic acid is the most studied compound and is considered a sensitive biomarker of the intoxication of susceptible plants that accumulate the compound in the presence of glyphosate (Harring et al., 1998; Schrübbers et al., 2014), while the resistant plants do not show an impressive increase after exposure to the herbicide (Singh \& Shaner 1998; Bonini et al., 2009). The quinic acid, which is an intermediate compound of the shikimic acid pathway, can also accumulate in plants after the application of glyphosate (Orcaray et al., 2010), and it may also be used as a marker of intoxication and sensitivity of the plants to the herbicide.

Due to the large use of glyphosate in agriculture, the interest in the development of analytical methods to detect and quantify its activity and its metabolites has increased (Alcaide-Molina et al., 2013). Several methods for determination of some of these compounds are reported both by spectrophotometry (Zelaya et al., 2011) and by liquid chromatography coupled to mass spectrometry (Raji et al., 2014) and detection by fluorescence (Zhang et al., 2013), or arrangement of photodiodes (Matallo et al., 2009; Alcaide-Molina et al., 2013) and gas chromatography with mass detector (Catrinck et al., 2013). However, the adoption of only one method of extraction and quantification of glyphosate, AMPA (aminomethylphosphonic acid) and compounds related to the shikimic acid pathway has not been reported. Given the above, this study aimed to develop a method of simultaneous extraction and determination by LC-MS/MS of glyphosate, AMPA and some of the main compounds involved in the shikimic acid pathway which are indicators of intoxication of plants by glyphosate.

\section{MATERIALS AND METHODS}

\section{LC-MS/MS method development}

An analytical method was developed for the simultaneous quantification of the following 
compounds: glyphosate, AMPA, shikimic acid, quinic acid, phenylalanine, tyrosine and tryptophan. The method was developed in an LC-MS/MS system, composed by a high performance liquid chromatograph (HPLC) (Shimadzu, Proeminence UFLC) equipped with two pumps (LC-20AD), an autoinjector (SIL20AC), a degasser (DGU-20A5), a controller system (CBM-20A) and an oven (CTO-20AC) coupled to a mass spectrometer $(3200 \mathrm{Q}$ TRAP) (Applied Biosystems), a hybrid triple quadrupole. The quantitative analysis method used was MRM, whose main advantages are high sensitivity and reproducibility, low noise and simultaneous measurement of up to 100 compounds (Queiroga, 2009).

To develop the method for determining compounds and calibration curves, analytical standards were used with a high degree of purity ( $\geq 99 \%$ ) from Sigma Aldrich. The optimization of the conditions of the mass spectrometer was performed with direct injections in the equipment (infusions), with a standard analytical solution of $1 \mathrm{mg} \mathrm{L}^{-1}$ of each individual compound. From the infusions was chosen the electrospray ionization (ESI) as a mode of source ionization, since this one had produced the analyte ions in the liquid phase before they entered the mass spectrometer. The best conditions of the capillary voltage, cone voltage and collision energies were determined for the analysis of all compounds.

For each compound, the ionization mode allowing higher signal intensity was chosen. The negative ionization mode was used for the following compounds: glyphosate, AMPA, shikimic acid and quinic acid. For the three aromatic amino acids (phenylalanine, tyrosine and tryptophan), the positive ionization mode was used. After choosing these conditions, the ions to be monitored to quantify were selected.

For the development of the chromatographic method of separation of compounds and determination of the calibration curves, the composition of the mobile phase for the chromatographic separation was tested in various compositions and flow rates. As to the separation and detection of the compounds in the negative ionization mode, the best chromatographic conditions were obtained using column
Gemini $5 \mu \mathrm{C} 18110 \AA$ (150 mm x $4.6 \mathrm{~mm})$ and a mobile phase consisting of $5 \mathrm{mM}$ of ammonium acetate in water (phase A) and $5 \mathrm{mM}$ of ammonium acetate in methanol (phase B), each adjusted to $\mathrm{pH} \mathrm{7.0.} \mathrm{The}$ gradient used was: 0 minute $30 \%$ of phase B; 2.5 minutes $50 \%$ of phase B; 5 minutes $75 \%$ of phase B; 8.5 minutes $90 \%$ of phase B; and 15 minutes $30 \%$ of phase $B$, with a flow of $0.500 \mathrm{~mL} \mathrm{~min}{ }^{-1}$. For the aromatic amino acids in the positive ionization mode, the best conditions were column Synergi $2.5 \mu$ Fusion RP $110 \AA$ and the same mobile phases used for the analyses in the negative mode. The gradient used was: 0 minute $10 \%$ of phase B; 2 minutes $40 \%$ of phase B; 4 minutes $95 \%$ of phase B; and 12 minutes $10 \%$ of phase $\mathrm{B}$, with a flow of $0.250 \mathrm{~mL} \mathrm{~min}^{-1}$.

The total run time was 18 minutes for those compounds in the negative ionization mode and 15 minutes for the aromatic amino acids in the positive ionization mode. The retention time in minutes of each compound in the chromatographic column was 3.86 for glyphosate and shikimic acid, 3.69 for AMPA, 3.79 for quinic acid, 9.71 for phenylalanine, 6.84 for tyrosine and 10.31 for tryptophan.

For each compound the calibration curve was determined with the concentrations of the standards that covered the range of levels of the compounds found in the plant tissues, which was represented by the linear regression equation $y=a x+b$, where $b$ is the intersection of the calibration curve and $a$ is the slope of a straight line. After the development of the method, the samples were diluted so that their concentration were always within the concentration range of the standard used in the curve for quantitation.

\section{Plant material and treatments}

Eucalyptus seedlings (Eucalyptus urophylla platiphylla) and sugarcane (cultivar SP801842) were used to develop the method of extraction and quantification of glyphosate and AMPA and compounds related to the shikimic acid pathway. The seedlings were kept in tubes, and the stalks of sugarcane were planted in pots containing $1 \mathrm{~L}$ of Bioplant substrate (organic material of plant and expanded vermiculite) with pH 5.7 ( \pm 0.5 ) and kept in a greenhouse. 
When the eucalyptus and sugarcane plants had 6 to 8 leaves and 3 fully expanded leaves, respectively, glyphosate application was performed at a dose of 720 g e.a. ha ${ }^{-1}$ on 20 plants of each species. When applying the herbicide, a stationary spray was used consisting of a metal frame with a width of $2.0 \mathrm{~m}$. The bar was equipped with four nozzles XR 11002 vs spaced $0.5 \mathrm{~m}$ apart, placed at $0.5 \mathrm{~m}$ of height in relation to the experimental units. The working pressure of the equipment was $2.0 \mathrm{kgf} \mathrm{cm}^{-2}$, with a speed of $3.6 \mathrm{~km} \mathrm{~h}^{-1}$ and spray consumption of $200 \mathrm{~L} \mathrm{ha}^{-1}$. The commercial product used to prepare the spray solution was Roundup Original ${ }^{\circledR}$ (360 g a.e. $\mathrm{L}^{-1}$ ).

Two days after application (DAA), collecting all the leaves of eucalyptus and sugarcane plants was performed, which were washed three times with $50 \mathrm{~mL}$ of distilled water, so that the residue of the application, deposited on the leaves and not absorbed, were removed. After this procedure, the material collected for each species was divided into two equal parts: one of them was kept in an oven of forced air circulation at $45^{\circ} \mathrm{C}$ for 72 hours and the other was stored in a freezer at $-80^{\circ} \mathrm{C}$, being subsequently freeze-dried in a lyophilizer (Christ, alpha 2-4 LD Plus) at a temperature of $-70{ }^{\circ} \mathrm{C}$, also for 72 hours. After drying and lyophilization, the samples were ground in a mortar with liquid nitrogen. The material dried in an oven and lyophilized after being macerated was divided into three equal parts, which constituted three different replications for carrying out the tests to define the extraction methodology of the compounds.

\section{Extraction methodology}

After the plant samples were macerated, $100 \mathrm{mg}$ of the samples from the different methods of preparation were weighed which were placed in centrifuge tubes with $15 \mathrm{~mL}$ capacity. For each species and sample processing type (dried in an oven and lyophilized), three extraction solutions were tested: acidified water ( $\mathrm{pH}$ 2.5) (Matallo et al., 2009), acetonitrile-water (50:50) [v/v] and methanol-water (50:50) [v/v]. Three replicates were used for each type of processing of the plant material and extraction solution.

Ten milliliters of each extraction solutions were added in each sample, which were subjected to an ultrasonic bath with an ultrasonic frequency of $42 \mathrm{kHz}$ for 30 minutes. The extraction mechanism of a certain substance of a plant sample involves the diffusion of the solvent by means of the cell walls and washing such substance out of the cells, since the walls are broken, which is greatly influenced by the ultrasonic irradiation, particularly when the plant material is dry (Vinatoru, 2001). Thus, the ultrasound bath used in all tested extraction procedures has the function to facilitate the swelling and hydration of the dry material, and then result in increased permeability of the cell wall, increasing the process of diffusion and transfer of the substance to the extraction solution (Vinatoru, 2001).

Subsequently, the samples were subjected to centrifugation at 4,000 $\mathrm{g}$ for 10 minutes at $20{ }^{\circ} \mathrm{C}$. The supernatant was collected and filtered in a Millex HV 0,45 $\mu \mathrm{m}$ filter, with membrane Durapore $13 \mathrm{~mm}$, and packaged in an amber vial for subsequent quantification by high efficiency liquid chromatography and mass spectrometry (LC-MS/MS). According to the concentrations in the samples, the content of each compound extracted by gram of dry plants tissue was determined.

\section{Recovery factor}

To verify the recovery of the compounds in the vegetable matrix with acidified water as extracting solution, fortification of the samples was performed with a solution containing the mixture of the different analytical standards, so that it presented the contents of 50 and $100 \mu \mathrm{g} \mathrm{L} \mathrm{L}^{-1}$ of each compound; control plants were kept to be compared in order to determine the endogenous level of each compound in the plant before fortification. Three replicates were performed.

The means and standard deviation were calculated across the fortified samples with respect to the calibration matrix standards. The recovery factor $(\mathrm{R})$ was calculated from the equation: $\mathrm{R}(\%)=\left(\mathrm{C}_{1}-\mathrm{C}_{2} / \mathrm{C}_{3}\right) * 100$, where $\mathrm{C}_{1}$ is the concentration determined in the fortified sample; $\mathrm{C}_{2}$ is the concentration determined in the unfortified sample; and $\mathrm{C}_{3}$ is the concentration of the fortification (Gonçalves, 2007). 


\section{RESULTS AND DISCUSSION}

\section{Development of the analytical methodology}

The molar mass and the fragments generated from each molecule are shown in Table 1. The fragment used for quantification of each compound was always the product ion of the first transition, and the fragment (product ion) of the second transition was used for confirmation of the compound. For an unambiguous identification that allow the quantification of the compounds of interest in complex matrices, it is necessary to monitor more than one ion. For this reason, the use of the LC-MS/MS system enables the control of ionic transitions from the fragmentation of the molecular ion, ensuring the required sensitivity and the specificity necessary for the quantification of the analytes at sometimes trace concentrations present in high complexity matrices (Queiroga, 2009).
The analytical curves for the compounds were made in the concentration ranges shown in Table 2. The concentration of the shikimic and quinic acids in the sample is high due to the blockage of the metabolic pathway by glyphosate; therefore, the linear range for quantification of these two compounds was $75-4800 \mu \mathrm{g} \mathrm{L}^{-1}$, far superior to the other compounds analyzed. For the aromatic amino acids, the linear range was from 7.81 to $1,000 \mu \mathrm{g} \mathrm{L^{-1 }}$, and for glyphosate and AMPA, from 2.34 to $600 \mu \mathrm{g} \mathrm{L}^{-1}$. The coefficient of determination $\left(\mathrm{r}^{2}\right)$ for all compounds was 0.99 , except for the quinic acid, which showed $\mathrm{r}^{2}$ of 0.95; thus, the linear model used proved to be very suitable (Table 2).

The analytical method developed for quantifying the compounds by LC-MS/MS in the vegetable matrix, which is highly complex, has proved efficient for the simultaneous quantification of the following compounds: glyphosate, AMPA, shikimic acid and quinic acid, and for all three aromatic amino acids (phenylalanine, tyrosine and tryptophan).

Table 1 - Compounds quantified by LC-MS/MS in the negative and positive ESI (electrospray ionization) ionization mode and MRM acquisition mode, precursor ions and product ions and collision energy for both transitions

\begin{tabular}{|l|c|c|c|c|c|c|c|}
\hline \multirow{2}{*}{ Compound } & \multirow{2}{*}{$\begin{array}{c}\text { Molar } \\
\text { mass }\end{array}$} & \multicolumn{2}{c|}{$1^{\text {st }}$ Transition (quantification) } & \multicolumn{3}{c|}{$2^{\text {nd }}$ Transition (confirmation) } \\
\cline { 3 - 9 } & & Precursor ion & Product ion & $\begin{array}{c}\text { Collision } \\
\text { Energy (eV) }\end{array}$ & Precursor ion & Product ion & $\begin{array}{c}\text { Collision } \\
\text { Energy }(\mathrm{eV})\end{array}$ \\
\hline Glyphosate & 169.08 & 167.923 & 63.100 & -34 & 167.923 & 78.800 & -58 \\
\hline AMPA & 111.04 & 109.987 & 62.900 & -28 & 109.987 & 78.900 & -30 \\
\hline Shikimic acid & 174.15 & 173.008 & 93.000 & -22 & 173.008 & 111.000 & -16 \\
\hline Quinic acid & 192.17 & 191.037 & 84.900 & -30 & 191.037 & 93.000 & -30 \\
\hline Phenylalanine & 165.19 & 166.157 & 120.100 & 15 & 166.157 & 103.100 & 35 \\
\hline Tyrosine & 181.19 & 152.167 & 91.100 & 37 & 182.167 & 136.100 & 15 \\
\hline Tryptophan & 204.23 & 205.192 & 188.200 & 13 & 205.192 & 146.100 & 23 \\
\hline
\end{tabular}

Table 2 - Analytical curves and concentration ranges for each compound analyzed

\begin{tabular}{|l|ccc|}
\hline \multicolumn{1}{|c|}{ Compound } & Equation & $\mathrm{r}^{2}$ & $\begin{array}{c}\text { Linear range } \\
\left(\mu \mathrm{g} \mathrm{L}^{-1}\right)\end{array}$ \\
\hline Glyphosate & $\mathrm{y}=558 \mathrm{x}+26.5$ & 0.9976 & $2.34-600$ \\
AMPA & $\mathrm{y}=129 \mathrm{x}-168$ & 0.9982 & $4.68-300$ \\
\hline Shikimic acid & $\mathrm{y}=25.8 \mathrm{x}-52.3$ & 0.9900 & $75-4800$ \\
\hline Quinic acid & $\mathrm{y}=337 \mathrm{x}+3.34 .10^{4}$ & 0.9535 & $75-4800$ \\
\hline Phenylalanine & $\mathrm{y}=3.41 .10^{3} \mathrm{x}-343$ & 0.9988 & $7.81-1000$ \\
Tyrosine & $\mathrm{y}=845 \mathrm{x}+500$ & 0.9984 & $7.81-1000$ \\
Tryptophan & $\mathrm{y}=1.51 .10^{3} \mathrm{x}+2.47 .10^{3}$ & 0.9930 & $7.81-1000$ \\
\hline
\end{tabular}




\section{Extraction of compounds}

Compounds extractions were performed using different solvents with different polarities from the dry plant material in an oven and lyophilized. The method developed for the LC-MS/MS system makes it possible to quantify the different compounds from the injection of a single sample, which reduces the cost of sample preparation and chromatographic analysis, minimizing wear of the equipment and consumables; however, for this to be valid, setting a single extraction procedure is required. Figures 1-7 show the results of extraction of the compounds analyzed in the same run of the two plant matrices (sugarcane and eucalyptus) with the three solvents used (acidic water, acetonitrile 50\% and methanol 50\%).

For most compounds in both plant species, the samples dried in an oven allowed a better extraction, except for the shikimic acid and quinic acid in eucalyptus, which were better extracted from the lyophilized samples. The extraction of the compounds from previously dried samples is widely used because it prevents large experimental variations (Rocha et al., 2006), maintaining uniform samples without variations in moisture content and are thus more easily standardized.

The concern in working with dry samples is also justified, because previous studies have shown that the water content of samples in natura varies during the development of plants injury by glyphosate. Drying in an oven should always be prioritized due to the greater simplicity and lower cost of the equipment required for drying the samples in relation to lyophilization.

Glyphosate and its major metabolite (AMPA) in the tissues of sugarcane and eucalyptus have shown better results for the extraction from the sample dried in an oven, associated to the use of acidified water as a solvent (Figures 1 and 2). The presence of AMPA was not detected in the sugarcane samples extracted with methanol $(50 \% \mathrm{v} / \mathrm{v})$, regardless of its drying method. The shikimic and quinic acids (Figures 3 and 4) were best obtained from the plant material dried in an oven for the sugarcane matrix and from the lyophilized material for the eucalyptus matrix. In both cases, the acidified water is equal to or higher than the other solvents tested for extraction.

The shikimic acid extraction technique of plant tissues of soybean and sugarcane using water and extraction assisted by microwave, developed by Matallo et al. (2009), has promoted a high extraction efficiency, near $100 \%$, and a high level of sensitivity without interference from other compounds and without the use of more toxic reagents such as sulfuric acid, hydrochloric acid and alcohols.
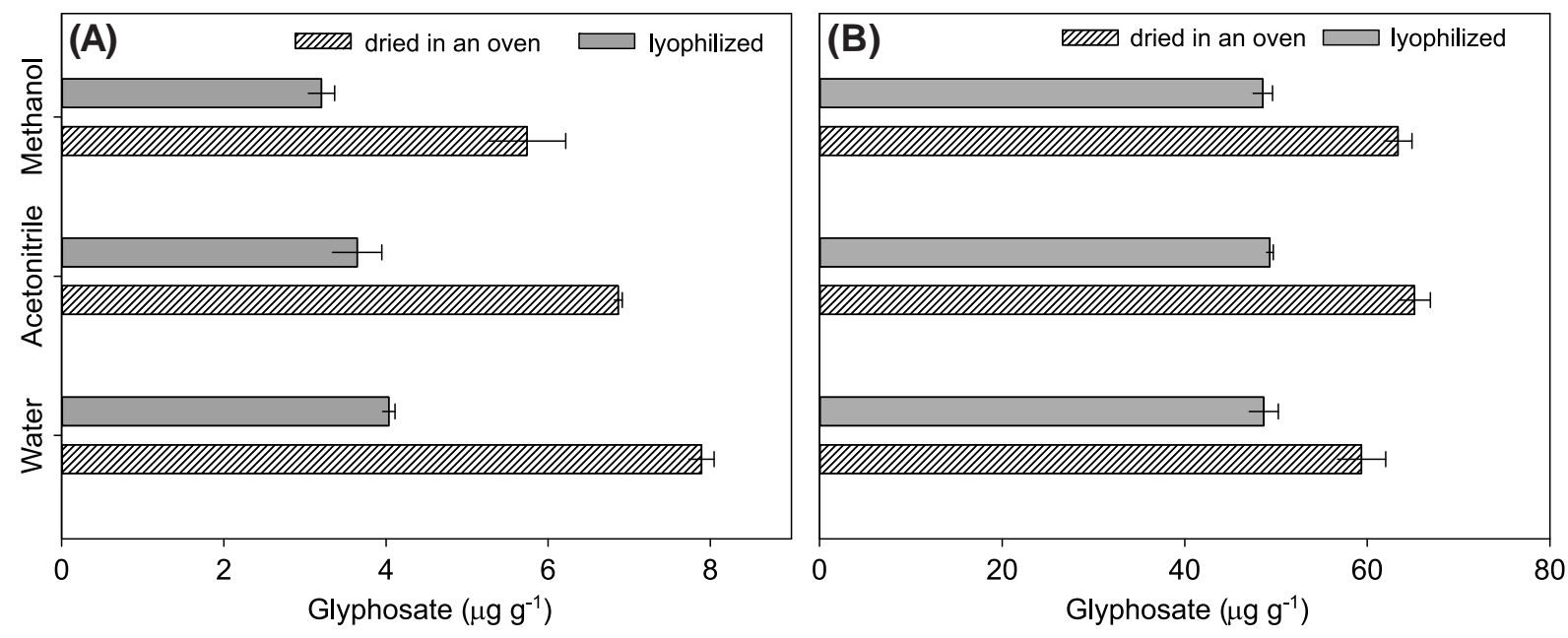

Figure 1 - Concentration of glyphosate $\left(\mu \mathrm{g} \mathrm{g}^{-1}\right)$ in sugarcane (A) and eucalyptus (B) plants in different methodologies of extractions. The error bar represents the mean standard error. 

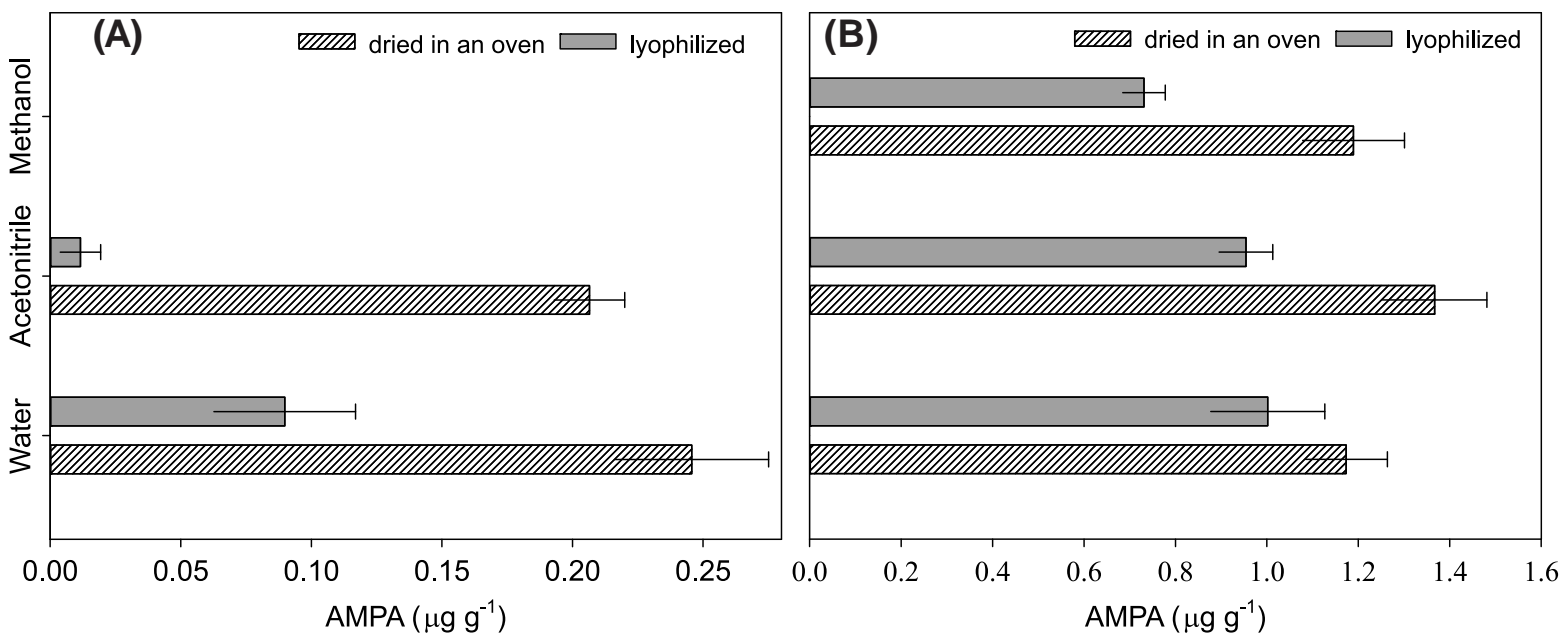

Figure 2 - AMPA concentration ( $\left.\mu \mathrm{g} \mathrm{g}^{-1}\right)$ in sugarcane (A) and eucalyptus (B) plants in different methodologies of extractions. The error bar represents the mean standard error.
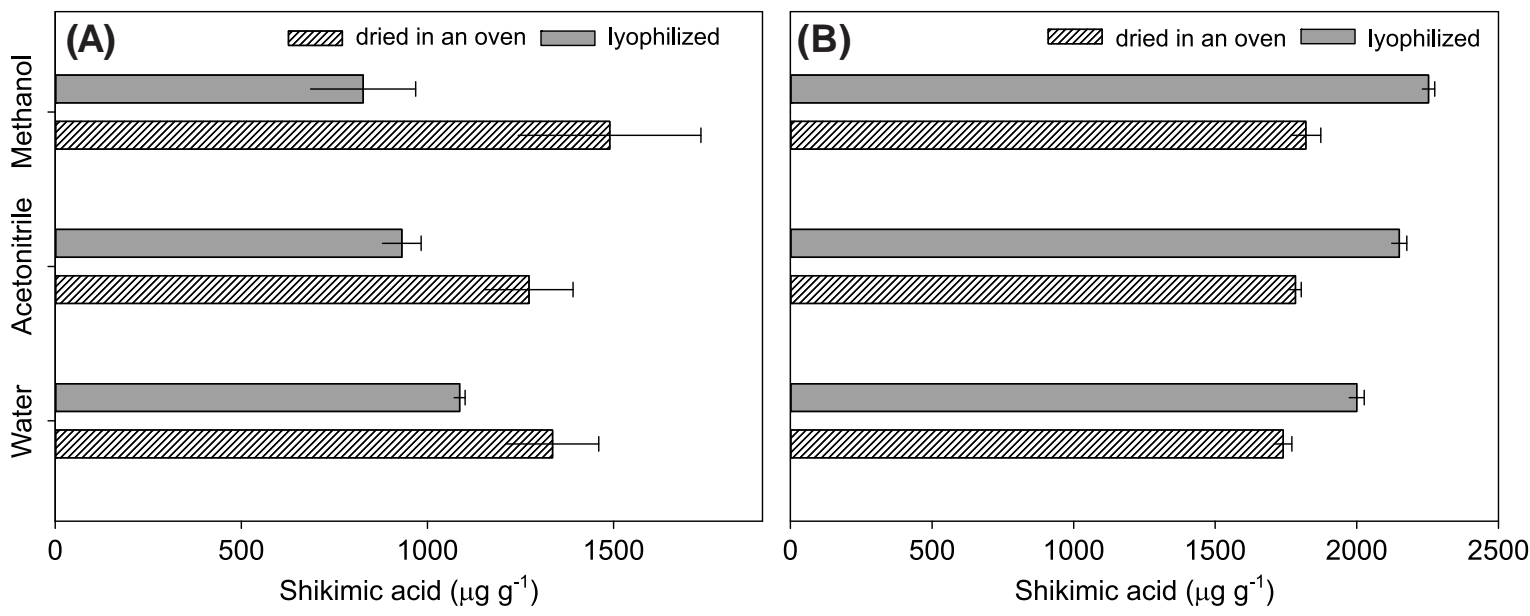

Figure 3 - Concentration of shikimic acid $\left(\mu \mathrm{g} \mathrm{g}^{-1}\right)$ in sugarcane (A) and eucalyptus (B) plants in different methodologies of extractions. The error bar represents the mean standard error.
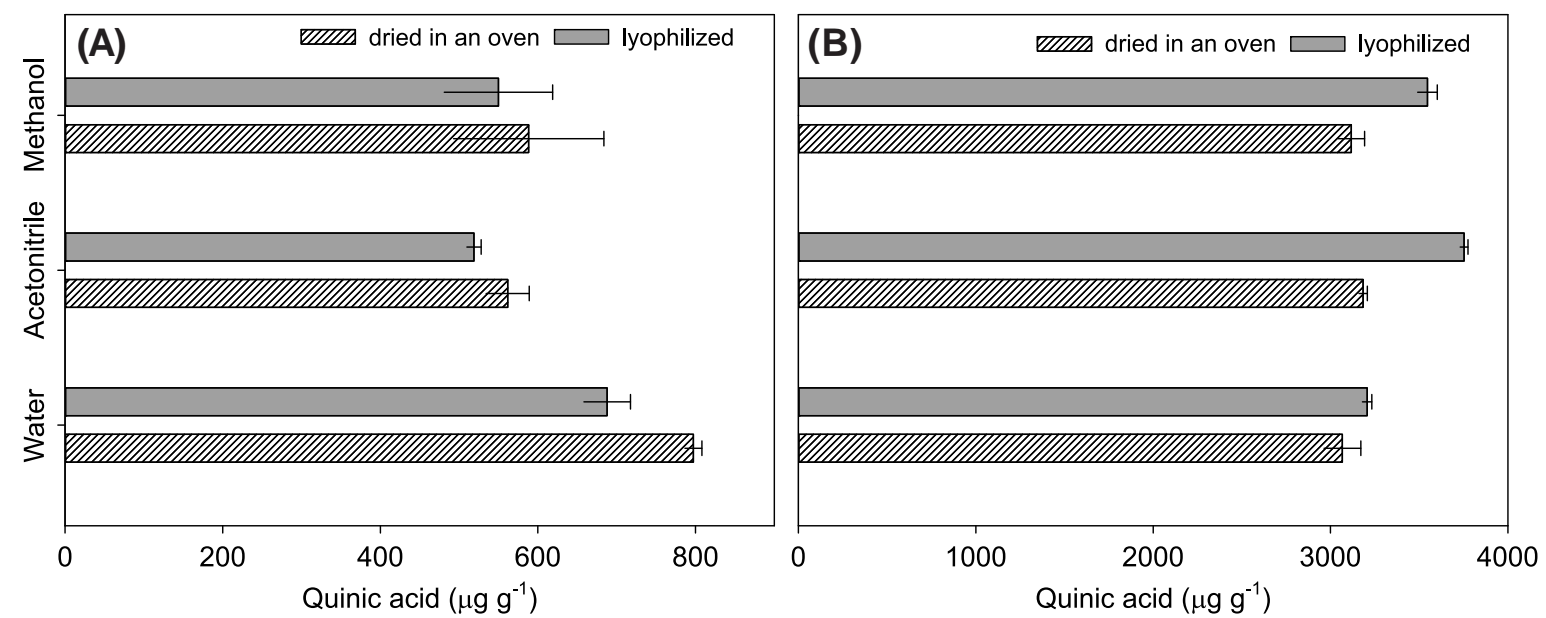

Figure 4 - Concentration of quinic acid $\left(\mu \mathrm{g} \mathrm{g}^{-1}\right)$ in sugarcane (A) and eucalyptus (B) plants in different methodologies of extractions. The error bar represents the mean standard error. 
The extraction of the three aromatic amino acids from the material dried in an oven in both plant species was equal to or, in most cases, higher than the extraction from the lyophilized material (Figures 5, 6 and 7). Again, the acidified water was the solvent that provided the best extraction of the amino acids of the vegetable matrices, except for tyrosine (Figure 6), which was easily extracted with methanol $(50 \% \mathrm{v} / \mathrm{v})$, followed by acetonitrile $(50 \% \mathrm{v} / \mathrm{v})$ and acidified water from the sugarcane material.

Although there have been a few exceptions, the extraction of the compounds from the plant material dried in an oven of the sugarcane and eucalyptus was higher than the freeze-dried one, and acidified water was the solvent with the best extraction of most of the compounds. The best combination of sample preparation and extraction solution was obtained from samples dried in an oven and with acidified water, because it represented lower costs, lower health risks to the people involved and disposal of the solvents (methanol and acetonitrile). Water is one of the most used solvents for glyphosate extraction because of its non-toxic characteristic and the solubility of the herbicide and its metabolites (Hogendoorn et al., 1999).
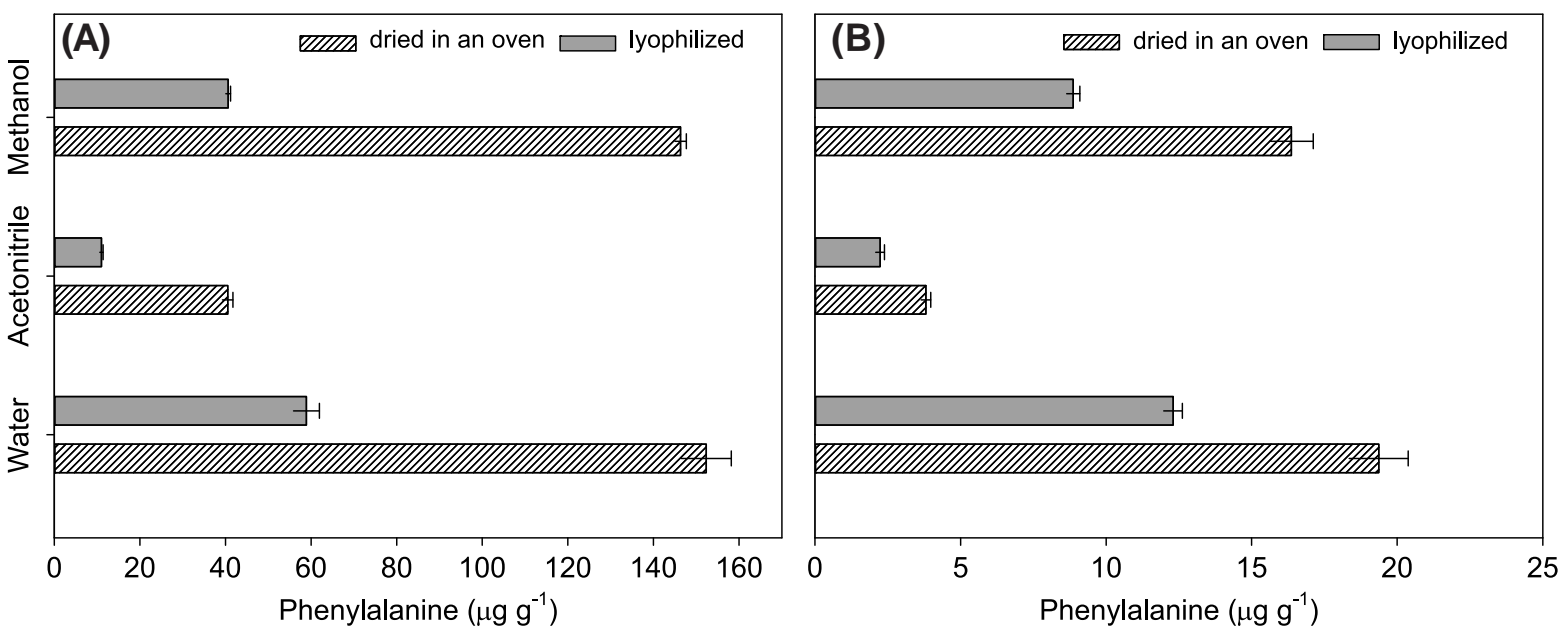

Figure 5 - Phenylalanine concentration $\left(\mu \mathrm{g} \mathrm{g}^{-1}\right)$ in sugarcane (A) and eucalyptus (B) plants in different methodologies of extractions. The error bar represents the mean standard error.
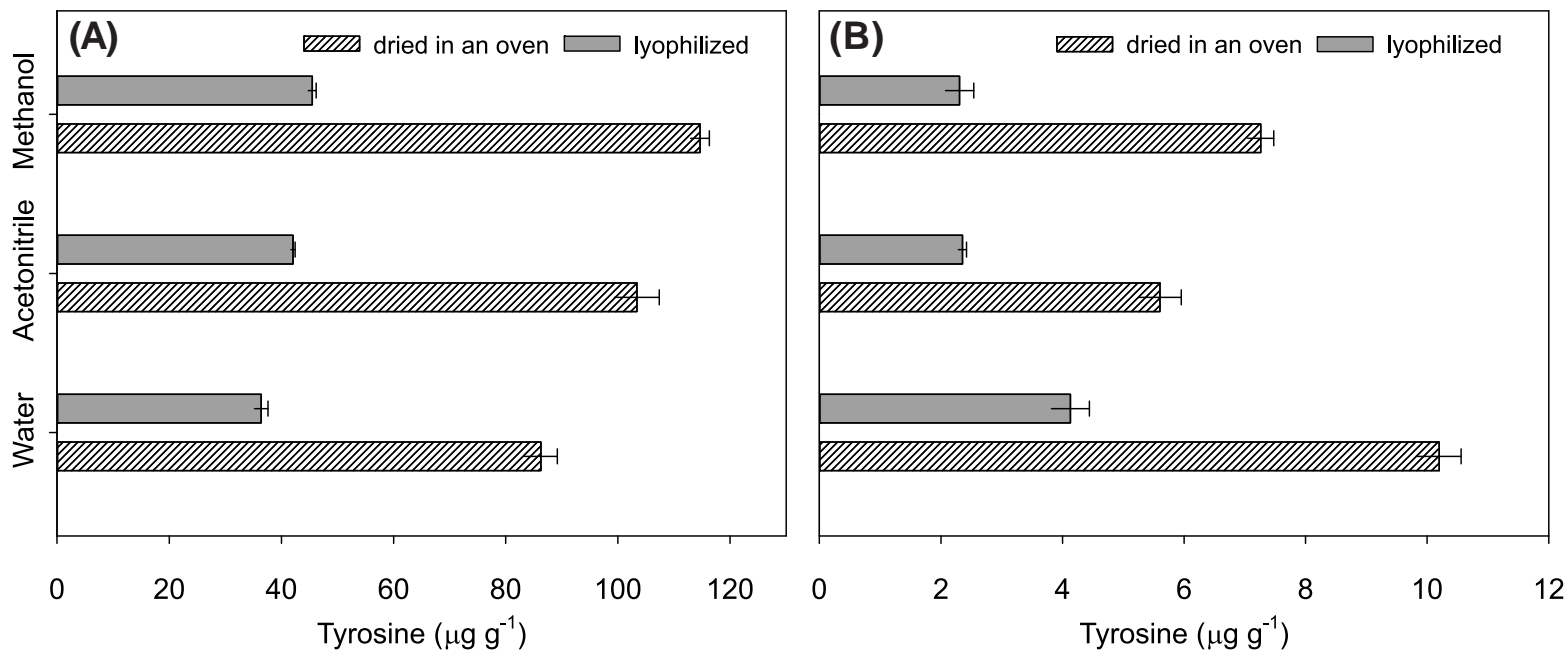

Figure 6 - Tyrosine concentration ( $\left.\mu \mathrm{g} \mathrm{g}^{-1}\right)$ in sugarcane (A) and eucalyptus (B) plants in different methodologies of extractions. The error bar represents the mean standard error. 

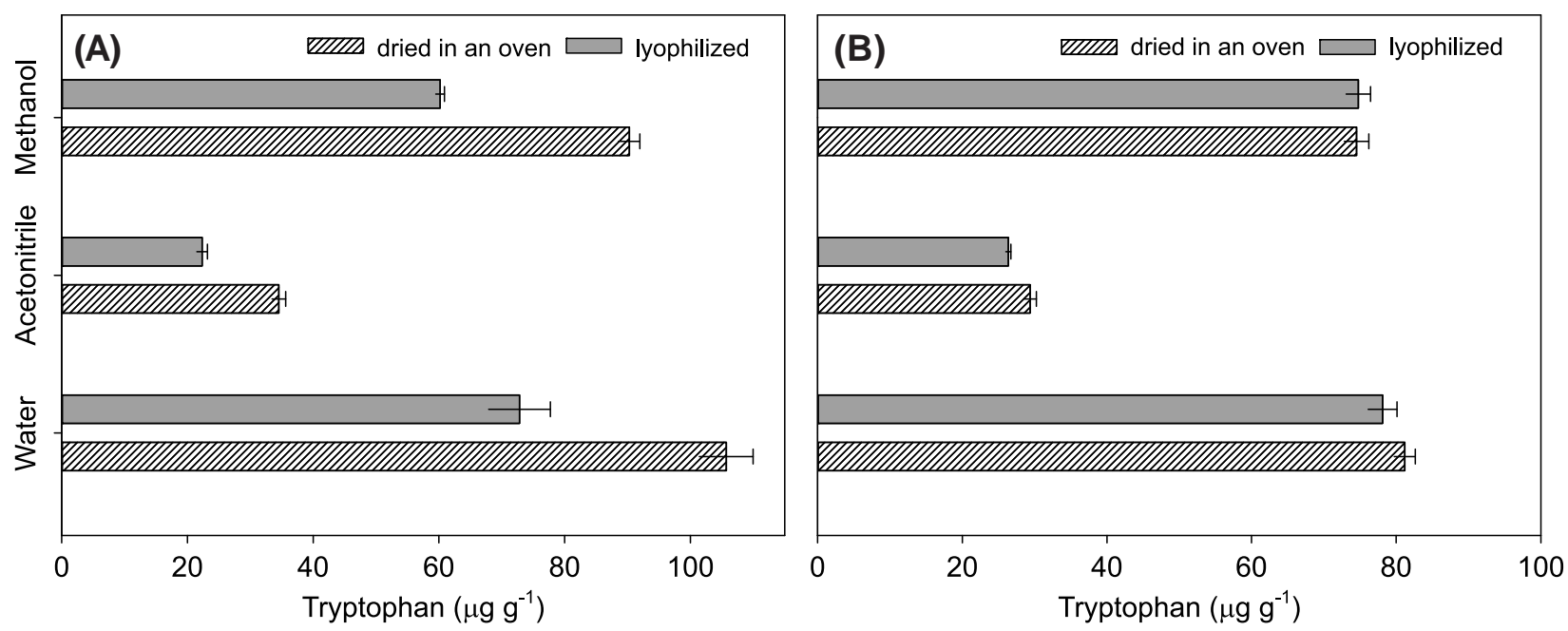

Figure 7 - Tryptophan concentration ( $\left.\mu \mathrm{g} \mathrm{g}^{-1}\right)$ in sugarcane (A) and eucalyptus (B) plants in different methodologies of extractions. The error bar represents the mean standard error.

\section{Recovery of the compounds}

According to the standardization of extraction of the samples from the material dried in an oven and using acidified water as a solvent, fortification of the samples with known concentrations of standard solutions of each compound was performed to determine their recovery levels. The recovery factor is the ratio between the levels of the substance of interest that is present or has been added to the material, which is extracted and can be quantified (Thompson et al., 1999).

In general, there were high recovery levels of the compounds in the samples fortified with known amounts of each compound for the two matrices (eucalyptus and sugarcane) (Table 3) which ranged from $74-101 \%$ in sugarcane and from $75-110 \%$ in eucalyptus. The highest levels were observed for all three aromatic amino acids, with a maximum recovery of tryptophan (101\%) followed by phenylalanine $(96 \%)$ and tyrosine $(95 \%)$ from the samples fortified with $100 \mu \mathrm{g} \mathrm{L} \mathrm{L}^{-1}$ of the standard solution in sugarcane. For eucalyptus, the amino acids were totally recovered in the fortified samples.

The lowest recovery levels, below $80 \%$, were observed for AMPA ( $\left.50 \mu \mathrm{g} \mathrm{L}^{-1}\right)$ from the two plant matrices, and for the shikimic and quinic acids $\left(100 \mu \mathrm{g} \mathrm{L}^{-1}\right)$ from eucalyptus. Even for these compounds, which had the lowest
Table 3 - Recovery levels for the addition of 50 and $100 \mu \mathrm{g} \mathrm{L}^{-1}$ of each compound in the fortified samples \pm standard error

\begin{tabular}{|c|c|c|}
\hline $\begin{array}{c}\text { Fortification } \\
\text { levels }\end{array}$ & $\begin{array}{l}\text { Recovery levels in } \\
\text { sugarcane }(\%)\end{array}$ & $\begin{array}{c}\text { Recovery levels in } \\
\text { eucalyptus }(\%)\end{array}$ \\
\hline \multicolumn{3}{|c|}{ Glyphosate } \\
\hline $50 \mu \mathrm{g} \mathrm{L}^{-1}$ & $84.2 \pm 5.05$ & 89.25 \\
\hline $100 \mu \mathrm{g} \mathrm{L}^{-1}$ & $88.3 \pm 3.88$ & 92.18 \\
\hline \multicolumn{3}{|c|}{ AMPA } \\
\hline $50 \mu \mathrm{g} \mathrm{L}^{-1}$ & $74.1 \pm 1.34$ & 75.44 \\
\hline $100 \mu \mathrm{g} \mathrm{L}^{-1}$ & $82.1 \pm 2.21$ & 84.31 \\
\hline \multicolumn{3}{|c|}{ Shikimic acid } \\
\hline $50 \mu \mathrm{g} \mathrm{L}^{-1}$ & $82.5 \pm 16.76$ & 99.26 \\
\hline $100 \mu \mathrm{g} \mathrm{L}^{-1}$ & $74.2 \pm 14.43$ & 88.63 \\
\hline \multicolumn{3}{|c|}{ Quinic acid } \\
\hline $50 \mu \mathrm{g} \mathrm{L}^{-1}$ & $87.0 \pm 7.91$ & 94.91 \\
\hline $100 \mu \mathrm{g} \mathrm{L}^{-1}$ & $76.2 \pm 20.91$ & 97.11 \\
\hline \multicolumn{3}{|c|}{ Phenylalanine } \\
\hline $50 \mu \mathrm{g} \mathrm{L}^{-1}$ & $83.7 \pm 8.73$ & 92.43 \\
\hline $100 \mu \mathrm{g} \mathrm{L}^{-1}$ & $96.06 \pm 4.89$ & 100.95 \\
\hline \multicolumn{3}{|c|}{ Tyrosine } \\
\hline $50 \mu \mathrm{g} \mathrm{L}^{-1}$ & $93.2 \pm 5.08$ & 98.28 \\
\hline $100 \mu \mathrm{g} \mathrm{L}^{-1}$ & $95.4 \pm 6.83$ & 102.23 \\
\hline \multicolumn{3}{|c|}{ Tryptophan } \\
\hline $50 \mu \mathrm{g} \mathrm{L}^{-1}$ & $96.2 \pm 6.04$ & 102.24 \\
\hline $100 \mu \mathrm{g} \mathrm{L}^{-1}$ & $101.0 \pm 9.75$ & 110.75 \\
\hline
\end{tabular}


recovery percentages, the results are satisfactory, because, for detection of residues, recovery should be between 70 and $120 \%$, and depending on the analytical complexity of the sample, this value can be 50-120\% (Ribani et al., 2004). The recovery factor is an indicator of the accuracy of the method, and the high values obtained allow confirmation that there was no degradation of the compounds during the extraction process (Alcaide-Molina et al., 2013).

\section{ACKNOWLEDGMENT}

To FAPESP (São Paulo Reseach Foundation) and CNPq (National Council for Scientific and Technological Development) for the financial support for this study.

\section{LITERATURE CITED}

ALCAIDE-MOLINA, M. et al. Sequential determination of metabolites involved in the biosynthesis of aromatic amino acids after ultrasound-assisted extraction from plants and reverse LC separation. Talanta, v. 105, p. 429-434, 2013.

BONINI, E. A. et al. A simple chromatgraphic assay to discriminate between glyphosate-resistant and susceptible soybean (Glycine max) cultivars, Eur. J. Agron., v. 31, n. 3, p. 173-76, 2009.

CATRINCK, T. C. P. G. et al. Study of the reaction derivatization glyphosate and aminomethylphosphonic acid (AMPA) with N,O-bis(trimethylsilyl)trifluoroacetamide. Am. J. Anal. Chem., v. 4, p. 647-652, 2013.

GONÇALVES, F. F. Estudo de métodos empregando HPLC-DAD e LC-MS/MS para a determinação de resíduos de herbicidas em água e solo do cultivo de arroz irrigado. 2007. 127 f. Tese (Doutorado Química Analítica) Universidade Federal de Santa Maria, Santa Maria, 2007.

HARRING, T. et al. Accumulation of shikimic acid: A technique for screening glyphosate efficiency. J. Agric. Food Chem., v. 46, n. 10, p. 4406-4412, 1998.

HERRMANN, K. M. et al. The shikimate pathway. Ann. Rev. Plant Physiol. Plant Molec. Biol., v. 50, p. 473-503, 1999.

HOGENDOORN, E. A. et al. Rapid determination of glyphosate in cereal samples by means of pre-column derivatisation with 9-fluorenylmethyl chloroformate and coupled-column liquid chromatography with fluorescence detection. J. Cromatogr. A, v. 833, n. 1, p. 67-73, 1999.
MAEDA, H.; DUDAREVA, N. the shikimate pathway and aromatic amino acid biosynthesis in plants. Ann. Rev. Plant Biol., v. 63, p. 73-105, 2012.

MATALLO, M. B. et al. Microwave-assisted solvent extraction and analysis of shikimic acid from plant tissues. Planta Daninha, v. 27, p. 987-994, 2009. (Número Especial)

MATALLO, M. B. et al. Glyphosate as a tool to produce shikimic acid in plants. Planta Daninha, v. 32, n. 3 , p. 601-608, 2014.

ORCARAY, L. et al. The possible role of quinate in the mode of action of glyphosate and acetolactate synthase inhibitors. Pest Manag. Sci., v. 66, n. 3, p. 262-269, 2010.

QUEIROGA, C. L. Analisadores de massa: QTRAP. 2009 Disponível em: <http://www.espectrometriademassas.com.br/ capitulos/> Acesso em: $21 \mathrm{dez} .2010$.

RAJI, M. et al. Determination of inter-leaf translocated free glyphosate in Arabidopsis thaliana using liquid chromatography tandem mass spectrometry (LCMS/ MS) after derivatization with fluorenylmethyloxycarbonyl chloride (FMOC-Cl). J. Anal. Bioanal. Techn., v. 5, n. 2, p. 1-6, 2014.

RIBANI, M. et al. Validação em métodos cromatográficos e eletroforéticos. Química Nova, v. 27, n. 5, p. 771-780, 2004.

ROCHA, T. L. et al. Metabolômica: aplicações e perspectivas. Brasília: Embrapa, 2006. 38 p.

(Documentos, 189).

SCHRÜBBERS, L. C. et al. Glyphosate spray drift in Coffea arabica - Sensitivity of coffee plants and possible use of shikimic acid as a biomarker for glyphosate exposure. Pestic. Biochem. Physiol., v. 115, n. 1, p. 15-22, 2014.

SINGH, B. K.; SHANER, D. L. Rapid determination of glyphosate injury to plants and identification of glyphosateresistant plants. Weed Technol., v. 12, n. 3, p. 527-530, 1998.

THOMPSON, M. et al. Harmonized guidelines for the use of recovery information in analytical measurement, ISO, IUPAC and AOAC International Technical report. Pure Appl.

Chem., v. 71, n. 2, p. 337-348, 1999.

VINATORU, M. An overview of the ultrasonically assisted extraction of bioactive principles from herbs. Ultras.

Sonochem., v. 8, n. 3, p. 303-313, 2001.

ZELAYA, I. A. et al. Evaluation of spectrophotometric and HPLC methods for shikimic acid determination in plants: models in glyphosate-resistant and -susceptible crops. J. Agric. Food Chem., v. 59, n. 6, p. 2202-2212, 2011.

ZHANG, Y. et al. Determination of glyphosate and aminomethylphosphonic acid in soybean samples by high performance liquid chromatography using a novel fluorescent labeling reagent. Anal. Methods, v. 22, n. 5, p. 6465 - 6472, 2013. 